\title{
Give My Poor Heart Ease
}

\author{
Doug Newburg, PhD, Curt Tribble, MD
}

Division of Thoracic and Cardiovascular Surgery, University of Virginia Health System, Charlottesville, Virginia, USA

\section{WALKED HIGHWAY 6 I TILL I GIVE DOWN IN MY KNEES.}

I walked Highway 61 till I give down in my knees.

You know, I ain't found nobody to give my poor beart ease.

-James "Son Ford" Thomas, Leland, Mississippi [Ferris 2009]

\section{INTRODUCTION: THE ACADEMICAL VILLAGE}

I would make education a pleasant thing both to the teacher and the scholar. This discipline, which we allow to be the end of life, should not be one thing in the schoolroom and another in the street. We should seek to be fellow students with the pupils, and we should learn of, as well as with them, if we would be most belpful to them. - Henry David Thoreau

We came to The University of Virginia (UVA) within a year of each other nearly four decades ago: one (DN) to join the UVA basketball team during four of the best years of UVA basketball, and to earn 2 degrees, first in English and then in Sports Psychology; and the other (CT) to begin 7 years of training in general, vascular, thoracic, and cardiac surgery, which culminated with a faculty appointment in the UVA Department of Surgery, with part of the charge being to organize most of the Department's educational programs. Realizing that the education and training of medical students and surgical residents would require knowledge, skills, and understanding above and beyond the usual training of a resident in surgery, I (CT) started an informal, though enriching, attempt to find those on the grounds of the University who might share ideas and insights that could enhance the educational programs in the Department. This process embodied the vision of the founders of the University to create an "academical village" [Towler 1993]. Various people around the University were sought out, ranging from the Dean of the School of Architecture to faculty in the Darden School of Business, a former astronaut in the Physics Department, as well as engineers, artists, psychologists, and educators, all generously sharing their time and expertise. However, the most enduring relationship turned out to be with The Sports Psychology program based in the University of Virginia's Curry School of Education, where, at the time, one of us (DN) was getting a PhD in Sports Psychology. An alliance between a surgical educator and a sports psychologist seemed

Correspondence: Curt Tribble, MD, Professor of Cardiothoracic Surgery, University of Virginia Health System, Division of Thoracic and Cardiovascular Surgery, Box 800679, Charlottesville, VA, 22908; 434-243-9250 (e-mail: CGT2E@bscmail.mcc.virginia.edu). like a natural one, as we were both studying and teaching performers of various sorts, focusing on performance, leadership, and teamwork. This relationship eventually led to a more formal position, with DN joining the Department of Surgery as the Educational Coordinator for the Department. During the ensuing 15 years, we thought about, wrote about, and taught education and performance, while helping our students and residents develop into resilient physicians and surgeons [Towler 1993; Newburg 1995; Newburg 1999; Sawyer 1999; Ellman 2005].

\section{SURGICAL TRAINEES AS PERFORMERS: THE UNWRITTEN CURRICULUM}

Would you turn to the page in this book that says where the mess ball is?

Well, that's not in the book, sir.

How did you know where the mess hall was if it's not in the book?

Well, I guess I just followed the crowd at chow time, sir. -A Few Good Men by Aaron Sorkin

We worked to enhance the ability of our protégés in The Department of Surgery to lead, teach, work with teams, and, most importantly, to perform as surgeons. Much of what we realized we needed to focus on is what has been called "the unwritten curriculum." This environment was a productive and successful one over the ensuing years, with the education and training of hundreds of medical students and dozens of surgical residents. Our most basic tenet during this era was "there had to be a better way" of organizing this educational environment to focus on helping our students and residents not only survive their trajectories but prevail as mature learners and practitioners in their chosen fields.

An important principle that we espoused was that each of our learners needed to know and regularly remind themselves why they had chosen to enter their respective trajectories. We put this principle into practice by starting all of our orientations by asking this question: Why are you here? These sessions were invariably memorable, emotional, and effective. We explained to our protégés that they had to constantly remind themselves of why they had chosen to enter the medical and surgical fields, in order to understand where they would get the energy needed to complete their long and sometime arduous trajectories from beginners to capable practitioners of whatever field of medicine they would choose for their life's work.

Another principle that we emphasized was summarized by this question: Does how you feel affect the way you perform? Virtually everyone, upon reflection, would answer that question in the affirmative. This question, and various approaches 
to answering it, resulted in a book entitled The Most Important Lesson No One Ever Taught Me [Newburg 2005].

We used various methods of enhancing these lessons including unusual ones such as taking groups of students and resident on trips out West to learn to snowboard, with the days culminating in what we described as "chautauquas" or discussions about learning and performance. These usually involved an eclectic group of additional participants in addition to our trainees coaches, Olympic athletes, musicians, and outdoor athletes [Tribble 2016c].

\section{THE STORY OF JR, A SENIOR SURGERY RESIDENT}

I can feel it coming in the air tonight...And I've been waiting for this moment for all my life.

-Phil Collins, In the Air Tonight

One of our senior residents, while preparing for a complex thoracic aortic repair, asked us for some advice about being ready to perform the operation. We pointed out that he had been preparing for this type of case for nearly his whole life, from high school sports to studying engineering in college, four years of medical school, and at least six years of surgical training. We assured him that he was ready to take this "next logical step." We urged him to trust his training and skills and to allow his feel of what would need to be done to guide him as he tackled this case. He reported later that he had used this approach with success to complete this difficult case with his faculty surgeon [Tribble 2016b].

\section{THE PATIENT AS PERFORMER}

To see what is in front of one's nose needs a constant struggle. -George Orwell

As the years passed, we came to realize that our focus on surgical trainees as performers was incomplete in that we had not, at least initially, considered that patients and their families were also performers as they engaged in their medical care, which in our realm usually involved undergoing various surgical procedures.

He who has a why to live can bear almost any how. -Friedrich Nietzsche

Initially, we realized that if we were to apply the principles we had used in the education of our various trainees to our patients, we needed to ask these patients to tell us why they had come to seek care in our system. We eventually learned that such conversations were most effectively started with this question: What do you want to do when you are well again? It turned out that everyone had an answer to that question. We have previously written about this strategy and our experiences with it, which evolved over time [Tribble 2016c]. Specifically, we asked the patients to not only tell us what they were going to do after recovering from their operations and treatments but to also promise to bring us a picture of themselves, doing what they had told us they would do when well again. There were many benefits to this strategy, some of which were obvious, while some more subtle. It is worth pointing out that the plan conveyed by the patients can be added into their charts, perhaps most appropriately becoming part of the Social History. Furthermore, this plan can be written on the white boards that hang in most patients' rooms, in hopes of generating conversations with the myriad healthcare providers who will be involved with each patient.

Finally, it is worth remembering that pictures of this sort will have value to the healthcare providers themselves. As we have pointed out to patients and families many times, not every day on a busy service providing care to complex patients is a good one. A picture collection, or even a few pictures on one's cell phone, can provide reminders to us, their doctors and nurses, of the good days.

\section{THE STORY OF GB}

One of the essential qualities of the clinician is interest in bumanity, for the secret of the care of the patient is in caring for the patient. - Francis Peabody, MD

A University of Virginia professor that both of us had encountered was referred to our service for a cardiac operation. We asked him what he wanted to do when well again, and he said that he wanted to be able to return to riding his bike to work, which seemed like a reasonable and laudable goal. He had a successful operation and recovered well. One day, sometime after he had returned for his routine follow-up visit, he turned up on the office schedule at the end of the clinic day, leading to concern that he was experiencing some difficulty. Upon entering his clinic room, the reason for his visit was immediately apparent. He had made a large poster from a photograph of himself riding his bike, and he had taped that poster up on the wall. So, rather than coming by to ask about something that might have been awry, he had come to colorfully demonstrate that things were, in fact, going very well. That picture has been a treasure among many other pictures like it ever since. Recently, I (CT) bumped into his family in the hospital cafeteria as they waited for him while he had an ablation procedure done for atrial fibrillation, which had been found incidentally during a routine office visit with his primary physician. They reminded me that our bike-riding former patient was still riding his bike, though I was startled by being reminded that we had done his operation 20 years earlier! They agreed to send me a 20 -year postop picture of him, still riding his bike, which has been added to my extensive collection of photos of patients doing what they had chosen to focus on prior to their operations.

\section{PROVIDING BETTER CARE: CLOSER TO HOME}

The worst mistakes involve not understanding people as well as you might. —Warren Buffet

During this era, a surgeon who trained at our institution, and who had committed the first 10 to 15 years of his career to providing medical and surgical care in a low-resource environment in another country, paid a visit to the Department during a break in his work. Our institution had provided 
some assistance to this surgeon and his team from time to time by sending outdated medical equipment, surplus supplies, and other materials to them. At a presentation about his work during this visit, he made the startling assertion that he and his team provided better care in their makeshift hospital than we did in our "state of the art, modern hospital." We were all certainly incredulous and said so. He told us that the key difference between these two environments was that they knew it was essential to bring the patient's home into the hospital while we, "back in America," at least tacitly created environments in the hospital that were "a far cry" from being like home. In our friend's hospital, one of the rules was that a patient could not be admitted to the hospital unless the family agreed that they would move into the patient's room and help provide most of the care needed for their family member, including food, bathing, bedding, physical therapy, and, perhaps most importantly, encouragement. Over the years since hearing this assertion made, we have thought long and hard about how we might emulate some aspects of that system to get the best of both worlds. This description prompted us to begin thinking of how we could take some of the strategies we were already using with our patients and take them to the next level.

\section{THE STORY OF MR}

I was born very far from where I was supposed to be, so I am on my way bome. - Bob Dylan

To explore and test our concepts about how the feel of a room matters, we asked a friend and colleague who was scheduled to undergo a major operation if she would permit us to utilize some of our ideas about creating an "environment friendly to recovery" in the room in which she would recuperate after her operation. She agreed to this plan enthusiastically. As the room was equipped only with a standard small, wall-mounted television, we rounded up a large-screen TV to which we attached a digital device on which we loaded digital content. This content included pictures of her family, quotations, music that was meaningful to her, and recordings from a TV channel that shows sunrises and sunsets in various locations. We taught the patient how to scroll through this content so that she could enjoy the images and the music. Of equal importance to the plan was the reminder that she needed to not only use this material for her own solace and enjoyment but also to show others, such as nurses, physical therapists, and consultants, what she wanted to do when she had recovered from the operation. All involved agreed that this fairly straightforward use of modern technology changed things in a remarkable way. She needed less pain medicine. Most felt that her recovery was speedier than expected. However, one of the most remarkable effects observed was how the ancillary healthcare providers felt when in her room. They acknowledged that they connected to the patient in ways that they generally did not in their usual work with similar patients. They reported that they understood the patient as a person, saw her as the healthy person she would once again be, and felt uplifted by the general feel of the room.
Changing the environment based on personal knowledge of the patient improved this patient's experience of the hospital room and the people in it for the better, including how she felt about both the room and her providers. While arranging this technology for this particular hospital stay was a bit cumbersome, it is apparent that more and more hospital rooms can be outfitted with devices that will make an approach of this type feasible in the near future.

\section{DISCUSSION: WE HAVE A PROBLEM}

How patients feel about their medical interactions really does influence the efficacy of the care they receive, and doctors' emotions about their work, in turn, influence the quality of the care they provide. - Atul Gawande, MD

The benefits to all involved of creating cultures and environments that are friendly to both learning and healing are obvious. Not only will patients benefit from the feel of such an environment, but the healthcare providers themselves will also be energized and inspired by it. Burnout among physicians and other healthcare providers is widespread. In an article in The Atlantic entitled "Doctors Tell All - and It's Bad," Meghan O'Rourke reviews a series of books by disillusioned physicians, and she notes that these books reveal "a corrosive doctor-patient relationship at the heart of our healthcare crisis." She notes that her essay is about "why it has become so difficult for so many doctors and patients to communicate with each other." Each of the books reviewed in this article reveals a crisis in "the very meaning and structure of care." One of the authors, a geriatric specialist, notes that "any patient in a hospital, when we take their clothes away, starts to lose identity. After a few days, they all start to merge into a single passive body, distinguishable .... only by the illnesses that brought them there." Ms. O'Rourke concludes her essay by noting that most patients will receive care in a system "that excels at stripping our medical shepherds of their humanity, leaving them shells of the doctors they want to be, and us [potential patients] alone in the sterile rooms they manage...I used to think that change was necessary for the patient's sake. Now I see that it's necessary for the doctor's sake, too." [O'Rourke 2014]

In a recent essay entitled "The Resilience Paradox," Dr. Ben Lovell, a medical educator, writes, "I have no idea how to teach resilience." He notes that while it is apparent that healthcare professionals need to be resilient, medical educators do not always know how to help their protégés acquire this resilience. He notes that developing resilience needs to be "transformative rather than restorative." Like other authors and educators, Dr. Lovell suggests that at least some of the resilience required of those working with difficult patients in challenging situations has to come from connecting in a personal, intimate way with their patients [Lovell 2017].

When one considers the costs of medical care, there is an increasing recognition that focusing on the expeditious return of patients to their home environments is necessary both for optimal patient care and for managing the costs of that care. In a recent article in the New England Fournal of 
Medicine entitled "Home-to Home Time - Measuring What Matters to Patients and Payers," Michael Barnett, MD, and his co-authors note that "thinking about episodes of care in terms of home-to-home time will require hospitals and postacute care facilities to form meaningful clinical relationships in order to coordinate patient care and measure important outcomes." [Barnett 2017]

Finally, in a recent editorial published in JAMA Psychiatry, Carol Ryff, PhD, of the University of Wisconsin, notes that a growing number of studies show that psychological wellbeing can be modified by positive and negative changes in a person's environment. While the primary focus of Dr. Ryff's editorial is on the patient's day-to-day environment, these same benefits seem likely to accrue in an optimized hospital environment [Ryff 2017].

\section{Conclusion: Taking Full Advantage of Life's Rich Pageant}

We all start out knowing magic. We are born with whirlwinds, forest fires, and comets inside us. We are born able to sing to birds and read the clouds and see our destiny in grains of sand. But, then we get the magic educated right out of our souls. We get it churched out, spanked out, washed out, and combed out... The truth of life is that every year we get farther away from the essence that is born within us... Life itself does its best to take that memory of magic away from us. You don't know it's happening until one day you feel you've lost something, but you're not sure what it is. -Robert McCammon, Boy's Life

We believe it is imperative that, as healers, we search for as many approaches and strategies as we can find to help our patients retain their sense of self and keep in sharp focus their dreams of being well again. And in doing so, we can not only help the patients recover but we can also help their healthcare providers retain their own humanity, sanity, and resilience.

\section{REFERENCES}

Barnett M, Grabowski D, Mehrotra A. 2017. Home-to-home time measuring what matters. N Engl J Med 377:4-6.

Ellman PI, Kron IL, Alvis JS, et al. 2005. Acute sleep deprivation in the thoracic surgical resident does not affect operative outcomes. Ann Thorac Surg 80:60-4.

Ferris W. 2009. Give My Poor Heart Ease: Voices of the Mississippi Blues. University of North Carolina Press. ISBN: 978-0-8078-3325-4

Lovell B. 2017. The resilience paradox. J Grad Med Ed 9:533-4.
Newburg DS, Tribble CG. 1995. Remember and forgive: The incorporation of the principles of sports psychology into a curriculum of surgical education. J Perform Ed 1:25-8.

Newburg DS, Tribble CG. 1999. Mental strategies in surgery. J Excellence $2: 1-18$.

Newburg, D. 2005. The Most Important Lesson No One Ever Taught Me. Xlibris Corporation. ISBN 1-4134-9025-5.

O'Rourke M. Doctors Tell All - And It's Bad. 2014. The Atlantic. www.theatlantic.com/magazine/archive/2014/11/ doctors-tell-all-and-its-bad/380785/

Ryff C. 2017. The Benefits of Purposeful Life Engagement on Later-Life Physical Function. JAMA Psychiatry. doi:10.1001/ jamapsychiatry.2017.2136.

Sawyer RG, Tribble CG, Newburg DS, Pruett TL, Minasi JS. 1999. Intern call schedules and their relationship to sleep, operating room participation, stress, and satisfaction. Surgery 126:337-42.

Towler MA, Abidin MR, Tribble CG. 1993. Edlich's academical village. J Emerg Med 11:353-7.

Tribble CG, Newburg D. 1998. Teaching the mental side of surgery. J Excellence 1:6-19.

Tribble CG, Newburg D. 2000. Patients as performers. J Excellence 3:6-18.

Tribble CG, Newburg D. 2001. Attracting medical students to careers in surgery. Current Surgery 59:327-9.

Tribble C. 2016. Always keep your clothes in the car. Heart Surg Forum 19: $237-40$.

Tribble C. 2016. Failing to prepare is preparing to fail. Heart Surg Forum 19:112-5.

Tribble C. 2016. Gimme three steps: Increasing patient satisfaction, decreasing physician burnout. Heart Surg Forum 19:80-1.

\section{ADDITIONAL REFERENCES}

Kraft-Todd G. 2017. Does empathy and warmth make a physician seem more competent? New research suggests that in many cases the answer isyes. Scientific American Blogs. blogs.scientificamerican.com/observations/ does-empathy-and-warmth-make-a-physician-seem-more-competent/

Peabody FW. 1984. Landmark article March 19, 1927: The care of the patient. JAMA 252:813-8.

Tribble C, Merrill W. 2014. The way we talk is the way we teach. J Thorac Cardiovasc Surg 147:1155-9.

Tribble C, Merrill W. 2016. In your own words: towards a more perfect union of patient care and education. Ann Thorac Surg 101:837-40. 